\title{
Impacts of Covid-19 remediation policies on gender equality and climate change in Son La and Thua Thien Hue provinces
}

\author{
Pham Thu Thuy, Tran Ngoc My Hoa, Nguyen Thi Van Anh and Nguyen Thi Thuy Anh
}

\section{Key messages}

- Covid-19 has had a significant impact on economic development in Vietnam, as well as on businesses, workers, communities and households in Son La and Thua Thien Hue provinces.

- To address the consequences of Covid-19, the Government of Vietnam and the People's Committees of Son La and Thua Thien Hue provinces have implemented a variety of policies in order to support businesses and individuals financially, such as reducing taxes and financial responsibilities; ensuring social security for underprivileged groups including women, children and ethnic minorities; and guaranteeing agroforestry and production areas. In addition to public financial resources, local governments and residents also mobilize support from public and private sector organizations in order to help Covid-19 recovery.

- Support from the government and the public has partly helped in reducing the impacts of Covid-19 on businesses and individuals. However, many challenges remain in developing and implementing policies, including: (i) many stakeholders face challenges having no timely access to information or the capacity to complete administrative procedures; (ii) state agencies' implementation processes are slowly falling behind schedule and are untimely due to overlapping and inconsistent instructions; and (iii) support is so slow that it only assists people in purchasing daily necessities but not in recovering from Covid.

- $\quad$ Current support policies are primarily aimed at assisting businesses, people infected with Covid-19 and workers. Support is extremely limited for ethnic minority groups and women and children. Covid-19 recovery policies should be considered in order to provide timely, accessible and relevant support to vulnerable groups' needs and capacities.

\section{Introduction}

Covid-19 has had a significant impact on the economic development and social security of Vietnam. As of September 2021, Vietnam's GDP had increased by only 1.42 percent over the same period in the previous year, with the agriculture, forestry and fisheries sector increasing by only 2.74 percent (GSO 2021). Covid-19 also reduced the number of newly established businesses and investment capital, while the number of businesses exiting the Vietnamese market increased by 15.3 percent (GSO 2021).

Social distancing acts have also had an impact on state budget revenue, putting Vietnam under pressure as the jobless rate rises. To mitigate the impacts of Covid-19, Vietnam has established a number of policies, including providing approximately VND 13.8 trillion in assistance to nearly 17.6 million individuals across the country, as well as distributing 136,349.6 tons of rice to over two million households with roughly 9.1 million people (GSO 2021). The implementation of these policies is well supported by Vietnamese people and businesses, but there has been no assessment of their effectiveness in overcoming the consequences of Covid-19, dealing with climate change and ensuring gender equality. This policy brief focuses on the effects of Covid-19, judging the effectiveness of policies designed to deal with the outcomes of the pandemic, and making recommendations for future policy amendments based on secondary documentation and research findings in the provinces of Son La and Thua Thien Hue.

Son La and Thua Thien Hue are two provinces in Vietnam with high poverty rates, large numbers of forest-dependent people, and some of the country's largest areas of forest. Both provinces are severely affected by climate change. As of November 2021, Son La and Thua Thien Hue each had 
over 1,300 people infected with Covid-19 (Nguyen and Duy 2021a; P 2021; CDC Son La 2021; Mai 2021; Anh 2021). Covid-19 has had significant economic and societal impacts in both provinces, particularly as businesses face numerous challenges. Covid-19 disrupts goods and services supply chains, causing shortages of raw materials for production of goods and aggregate demand of the economy, and of domestic and foreign buyers to fall sharply (GSO 2020; Luong 2021; Nguyen and Duy 2021b; Le NT 2021; Nhat 2021; Dinh 2021; Le 2021; Minh 2021; Portal of Son La province 2021a, 2021 b; Hau 2021). To be more specific, state budget revenues from a number of key sectors in the two provinces, such as electricity production in Son La and tourism in Thua Thien Hue, have also decreased dramatically compared to the same period prior to the Covid-19 outbreak. Many companies and businesses have had to reduce their workforce, or even close and declare bankruptcy. Until now, the proportions of public investment disbursed in Thua Thien Hue and Son La are only 64\% and 48\%, respectively.

Since the Covid-19 pandemic, large numbers of people living in or migrating to work from the two provinces have lost their jobs and incomes (Thu H 2021; Huu 2021). Currently, at least 2,500 people in Son La are unemployed, while approximately $23 \%$ of workers in Thua Thien Hue's small and medium-sized enterprises have lost their jobs (Luong 2021; Nguyen and Duy 2021b; Le NT 2021; Nhat 2021; Dinh 2021; Le 2021; Minh 2021; Portal of Son La province 2021a, 2021 b; Hau 2021). Son La province has received a large number of Covid-19 cases from Binh Duong, Hanoi, Bac Giang, Phu Quoc, Dong Nai, Phu Tho, and Ho Chi Minh City (Mai 2021), with 3,000 people returning to Son La from these provinces between 5 October and 18 October (Thu 2021a,b; Huyen 2021). More than 110,000 local workers had gone to other provinces for work, but more than half of them have returned since the Covid-19 pandemic (Nguyen and Duy 2021b). People from Son La who migrate to cities to work can earn up to VND 7 million/month and save VND 1 million/month, but their lives become very difficult if they are unable to continue working as hired labourers (Nguyen and Duy 2021b). Many policies and projects have recently been launched to address the consequences of Covid-19, and reviewing their efficacy will provide timely changes and improve their effectiveness.

\section{Policies for providing support and mitigating the effects of Covid-19}

Vietnam has implemented 12 policies to tackle the effects of Covid-19 (Box 1).

\section{Box 1.12 major policies to provide support in tackling the consequences of Covid-19}

1. A policy aimed at lowering insurance premiums for occupational accidents and diseases

2. A policy on the temporary suspension of contributions to the retirement and survivorship fund

3. A policy to support employee training and job retention

4. A policy to assist employees whose labour contracts have been suspended or gone unpaid

5. A policy to assist employees who decide to leave their jobs

6. A policy to assist employees whose labour contracts are terminated

7. A policy to provide additional support for children

8. A food allowance of VND 80,000 per person per day for people being treated for Covid-19 infection (F0)

9. One-time support of VND 3,710,000 per person for art directors, actors and painters

10. A policy to assist business households

11. A loan policy to pay wages during work stoppages and prior to resumption of production

12. A policy to assist workers without labour contracts (freelance workers), as well as other specified subjects.

Many policies have been implemented in Son La and Thua Thien Hue provinces to ensure social security, financial support, income tax exemption and reduction, and land tax (Prime Minister 2021; Son La Provincial People's Committee 2021; Son La Provincial People's Council 2021; VSS 2021; Thuy 2021; MOLISA 2021a; National Assembly Standing Committee 2021; Huu 2021; Pham et al. 2021; People's Committee of Thua Thien Hue province 2021a, 2021 b; Khanh 2021; Online Newspaper of the Government 2021; Hoang 2021; Duong et al. 2021).

\section{Tax exemption, tax reduction, tax payment extension} and credit support: Resolution No. 406/NQ-UBTVQH15 promulgates a number of solutions to assist businesses and people affected by the Covid-19 pandemic, including a $30 \%$ reduction in corporate income tax payable in 2021; exemptions from personal income tax, value added tax and other payable taxes arising from production and business activities for months in the third and fourth quarters of 2021 for households and individuals engaged in production and business activities; reduced value added tax on goods and services from 1 November 2021 to 31 December 2021; and exemptions for businesses and organizations that incurred losses in 2020 from late payment interest on taxes, land use levies, and land rent debts arising in 2020 and 2021 (Son La Provincial People's Council 2021). The Government 
also issued Decree No. 52/2021/ND-CP on 19 April 2021, extending the deadline for payment of 2021 value added tax, corporate income tax, personal income tax and land rent (Prime Minister 2021). This policy has benefited more than 94 percent of Son La's businesses and organizations (Son La Provincial People's Committee (2021). Furthermore, many businesses in both provinces have received credit assistance, debt restructuring, interest exemption and reduction, and loans for new production and business (An 2021; Son La Provincial People's Council 2021).

\section{Policies to help workers, people involved in epidemic} prevention work, and the general public: The Government has issued Resolution No. 68/NQ-CP and the Prime Minister issued Decision No. 23/2021/QD-TTg requiring the implementation of a number of policies to assist employees and employers experiencing difficulties as a result of the Covid-19 pandemic. In Son La, Resolution No. 04/2021/NQ-HDND and Decision No. 2270/QD-UBND on regulations on support policies stipulate the following: remunerations for forces established by the province and district level participating in interdisciplinary working groups at checkpoints to prevent and control the spread of Covid19 in the province are as follows: VND 130,000 per person per shift (8 hours); VND 80,000 per person per day for food; one-time support of VND 500,000 per person for labourers from poor households and VND 300,000 per person from near-poor households returning to their communities from epidemic areas; support at a rate of VND 50,000 per person per day for people laid off due to a temporary suspension of production and business for less than 30 days; and onetime support of VND 1,500,000 per person for workers laid off due to a 30-day or longer suspension of production and business. Where provisions specified in this Resolution and the policy promulgated by the Central Government coincide, only the policy with the highest level of support shall be applicable.

Meanwhile, the Ministry of Labour, Invalids, and Social Affairs issued Decision No. 1220/QD-LDTBXH on the implementation of policies from the Unemployment Insurance Fund to assist employees and employers affected by the Covid-19 pandemic. This policy document provides monetary support from the Unemployment Insurance Fund's balance to employees participating in unemployment insurance; monetary support from the Unemployment Insurance Fund's balance to employees who have stopped participating in unemployment insurance; and reductions in unemployment insurance premiums for employers affected by the Covid-19 pandemic. In addition, the Vietnam Social Security Administration issued Official Letter No. 2311/BHXHCSYT on the implementation of advance payment, payment of medical expenses, and health insurance coverage to ensure funding for medical treatment for health insurance participants. There is no shortage of funds to purchase drugs, chemicals and medical supplies at health care facilities that are covered by health insurance and do not allow patients to pay their own expenses within the scope of their prescribed benefits under Resolution No. 116/NQ-CP and Official Letter No. 1652NPUB-KGVX from the Unemployment Insurance Fund on policies to assist employees and employers affected by the Covid-19 pandemic.

Land rent reduction: Decision No. 27/2021/QD-TTg provides a 30\% reduction in land rent in 2021 for organizations, units, enterprises, households and individuals (referred to as land tenants) directly leased land by the State in the form of annual land rental payments under Decisions or Contracts of competent state agencies affected by the Covid-19 pandemic.

Trade support and promotion: Son La Provincial People's Committee issued Plan No. 224/KH-UBND to implement Resolution No. 105/NQ-CP dated 9 September 2021 in developing business activities of enterprises, cooperatives and business households. Previously, the province's trade promotion strategy was centred on organizing trade promotion conferences and connecting domestic and foreign agricultural product consumption. Son La Province has organized online conferences, linked agricultural product consumption, and has a plan to circulate goods between localities in the country and localities with border gates for agricultural products (Nguyen 2021). In addition, both Son La and Thua Thien Hue provinces have policies in place to attract investment and projects. In Son La, the Son La Provincial People's Committee issued Decision No. 902/QD-UBND on 15 May 2021 on the list of investment attraction projects in Son La province from 2021 to 2025. As a result, there are 239 projects attracting investment in the province, Son La city is implementing 17 urban development projects (eight province projects and nine city projects) on a scale of 96.75 ha (Portal of Son La province 2021a, 2021b). Meanwhile, Thua Thien Hue has licensed 27 new projects and adjusted to increase capital for eight projects with total new and additional investment capital of VND 13,904 billion in 2021 (Portal of Son La province 2021a, 2021 b; Nhat 2021; Hau 2021).

\section{The critical role of policies in mitigating the impacts of Covid-19}

Many necessary conditions have been created as a result of policies to assist businesses and residents of Son La province in overcoming the consequences of Covid-19.

Policy on social security: In 2020, VND 24.9 trillion was provided to Covid-affected parties, of which VND 13.4 trillion was provided to those directly affected by the Covid-19 epidemic, VND 4.1 trillion was provided to policy beneficiaries 
and people with meritorious services, and VND 3.1 trillion was provided to poor and near-poor households, while 26.6 million health insurance cards and free medical examinations and treatment books/cards were distributed (GSO 2020).

Policies for businesses and employees: Many businesses have benefited from the state's support policies in a timely manner. For example, the Social Policy Bank's Son La branch has provided loans to 12 businesses totalling more than VND 2.5 billion in order to pay workers' salary. (Nguyen and Duy 2021a). It is expected that 43,479 people will receive unemployment insurance benefits ranging from VND 1.8 to 3.3 million, for a total of VND 99.13 billion (Thuy 2021). More than 1,600 units and businesses in Thua Thien Hue are eligible for a policy that lowers insurance premiums for occupational accidents and diseases, and allows employers to temporarily suspend contributions to the retirement and survivorship fund (Nguyet 2021). Currently, Son La has approved a list and funding to support 867 business households, employees who temporarily suspend the performance of labour contracts or take unpaid leave, and more than 1,200 businesses in the area to reduce unemployment and occupational accident insurance contributions for approximately 19,000 employees (Nguyen and Duy 2021a). Currently, approximately 4,000 employees will benefit from the policy for employees from poor households and near-poor households living in epidemic areas returning to their localities; supporting people who have been laid off due to production and business suspensions for less than 30 days, and supporting people who have been laid off due to production and business suspensions for 30 days or more at one time, with a budget of approximately VND 5.7 billion (Nguyen and Duy 2021a).

Policies for the people and the community: The People's Committee of Son La province spent VND 11.1 billion in accordance with Prime Ministerial Resolution No. 68/NQ-CP dated 1 July 2021 and Decision No. 23/2021/QD-TTg dated 7 July 2021. The Government and workers should be guided to focus on husbandry and cultivation to stabilize their lives, and employment service centres should be promoted to strengthen the link between labour supply and demand with companies and enterprises outside the province so that local workers have jobs and income (Thu 2021a; P 2021). Son La also focuses on assisting enterprises, cooperatives and households in investing in cold storage warehouses, refrigerated containers, hot and cold steam drying ovens, and the application of machinery and equipment for the preliminary processing, processing and preservation of agricultural products (Nguyen 2021). Furthermore, Son La is constantly promoting connections with agricultural product processing factories outside the province in order to support the purchase and processing of fresh fruits into dried and flexible fruit products, so that if the pandemic situation is stabilized, agricultural products can continue to be exported, processed and sold in the domestic market (Nguyen 2021). Thua Thien Hue also implemented Government Resolution 68/NQ-CP dated 1 July 2021 on assisting employees and employers experiencing difficulties as a result of the Covid-19 pandemic, as well as Resolution No. 42 at the end of May 2021, approving and supporting 41,081 subjects totalling more than VND 45.8 billion (Thai 2021).

Policies for women and children: On 8 September 2021, the Ministry of Labour, Invalids, and Social Affairs issued Decision No. 1013/QD-LDTBXH on support for children of pregnant women infected with Covid-19 for the period 27 April 2021 to 31 December 2021, with a support level of VND 1,000,000 per child (MOLISA 2021b).

Policies that help ethnic minorities: The Committee for Ethnic Minority Affairs issued Decision No. 567/QD-UBDT on 1 September 2021, approving funding to support ethnic minorities from poor, near-poor and difficult-to-support households. As a result, the total amount of support for the Son La province is VND 176 million, with the following support levels: poor households receive VND 2,000,000 per household; near-poor households receive VND 1,000,000 per household; and disadvantaged households receive VND 500,000 per household. The aforementioned funding will contribute to timely encouragement for ethnic minorities infected with Covid-19 in provinces that are Covid hotspots, thereby assisting ethnic minorities in feeling secure and fighting the pandemic while striving to overcome all difficulties in life (Portal of Son La province 2021c). Son La province has also mobilized financial support from the people, business community and benefactors to support the Covid-19 Prevention and Control Fund with VND 32.1 billion in cash and a variety of goods and in-kind donations to help community Covid Teams assist workers who return to work in the provinces to ensure their social security (P 2021).

\section{Policy on Payment for Forest Environmental Services:} Although PFES was not intended as a policy to support effective Covid response, it has provided many people with an additional source of income to purchase daily necessities during periods of unemployment. The burden of people's living expenses has been partially shared with the money received from PFES, and the budget is spent on village community activities (Pham et al. 2021).

\section{Challenges in implementing support policies}

Despite the fact that the state has implemented many direct support policies to help businesses and people throughout the country, including in the two provinces of Son La and Thua Thien Hue, implementation of these policies continues to be difficult in practice. 
Firstly, current policy support programmes are primarily aimed at businesses and workers. While the policies help the poor, ethnic minority households that rely on forests or have limited financial resources only receive one-time, lowcost assistance, which is insufficient to support their needs. Furthermore, despite Directive No. 11/CT-TTg's support for businesses, only around 3\% of enterprises have access to the policy because leadership and management at all levels remain confused and inconsistent, lacks consistency, and lacks flexibility when the situation changes (Mai 2021; Le 2021). Even subsidized businesses are forced to lay off many workers in the face of declining revenue and market demand, thereby raising the unemployment rate.

Secondly, while there have been a number of policies to resolve and support the return of production investment, policies supporting farmers to maintain production and consumption chains to ensure their livelihoods face numerous difficulties (Nguyen 2021) because many smallscale household enterprises lack the capital to re-establish their economies. In Son La, enterprises and households involved in agroforestry, fisheries and aquaculture are estimated to have a capital shortfall rate of 36.84 percent (Portal of Son La province 2021a, 2021b). With no productive land and limited resources for reinvestment in agricultural production, the number of people wishing to relocate to cities will grow (Thu 2021a). Despite the risks, some people seek opportunities through illegal channels, becoming victims of human trafficking (Portal of the Ethnic Committee 2020).

Thirdly, current state budget spending prioritizes Covid19 prevention and control, national defence and security, well-implemented social security policies, encouraging investment, and export and import of goods and services (GSO 2021). In this context, many environmental, climate change and gender equality policies are being rolled back to make way for economic recovery as a priority.

Fourthly, ethnic minorities make up 14.7 percent of Vietnam's total population, but 95 percent of them are poor households, while poor women face many disadvantages in terms of gender equality and require assistance (Portal of the Ethnic Committee 2020). However, the distribution of social security benefits remains extremely slow (Mai 2021), meaning beneficiaries are not being reached in a timely manner during this difficult time. Furthermore, accessing and applying for state subsidies for ethnic minorities is difficult because the majority are illiterate or have limited access to the internet. The policy to support freelance workers and other specified subjects has been assigned to localities to develop criteria, and determine beneficiaries and levels of support, so implementation still faces a number of challenges. Furthermore, grassroots staff are stretched thin, working multiple jobs at the same time, resulting in a lack of timely guidance, reception and processing of documents for the people (Nguyet 2021). Furthermore, support is currently either cash or long-term capacity building support in forms such as vocational training, loans, guidance on implementing livestock and farming models, etc. These policies have not been designed or implemented to help women, particularly ethnic minority women (Duy 2021). Furthermore, Covid-19 has had a significant impact on poor and disabled women and children who were already vulnerable prior to the pandemic, and are now even more so with social distancing making it difficult for poor and isolated students to access education. The quality of meals has also decreased due to lower income, which affects children's physical and mental health and perception, while there are increasing risks for women and children in terms of domestic violence, gender-based violence and mental health. Despite the government's numerous support policies, many families are still ineligible for the support package under Resolution 42 because the procedure for receiving it is complicated, and the administrative procedures involved are time consuming. Even when households are eligible for receiving assistance, the meagre sum is insufficient to assist them in overcoming difficulties (Department of Social Protection, Ministry of Labour, Invalids and Social Affairs and Department of Labour, War Invalids and Social Affairs 2020).

\section{Conclusion}

Covid-19 has had a significant impact on Vietnam's economic and social development. To deal with and overcome the consequences of Covid-19, the Vietnamese government has devised and implemented a slew of social security and economic recovery policies. However, due to inconsistent administrative procedures and guidelines, these policies continue to face significant implementation challenges. Even when receiving state assistance, these packages only address and solve immediate and essential needs, are paid only once, and cannot guarantee the provision of long-term solutions. Ensuring equitable, timely and effective access to government assistance policies necessitates the simplification of administrative procedures, inter-sectoral coordination between stakeholders, and the combination and integration of numerous solutions. At present, with the goal of ensuring social security and economic recovery, current investment priorities and support policies have yet to focus on climate mitigation and adaptation solutions, or long-term environmental protection. Neglecting these issues may have long-term consequences for natural resource sustainability and may pose new environmental challenges in the future. While the assistance is only temporary and one-time, other environmental programmes and projects, such as Payments for Forest Environmental Services (PFES), have the potential to actively support revenue generation and stability for people living near forests. Given the importance of these 
environmental policies in the context of Covid-19, not only could stakeholders better understand the roles forests and PFES play, they could also diversify solutions to overcome the consequences of Covid-19.

\section{Acknowledgement}

This study was carried out with financial support from the CGIAR Gender Platform and the CGIAR Research Program on Forests, Trees and Agroforestry (FTA).

\section{References}

An C. 2021. Many localities are gradually returning to the "new normal". Portal of the Ministry of Industry and Trade. Accessed 15 November 2021. https://moit.gov.vn/tin-tuc/ dia-phuong/nhieu-dia-phuong-dang-dan-tro-ve-trangthai-binh-thuong-moi-.html

Anh K. 2021. The number of community COVID-19 infections increased, many schools in Hue switched to online teaching. People's Public Security Newspaper. Accessed 15 November 2021. https://cand.com.vn/giao-duc/so-canhiem-covid-19-cong-dong-tang-nhieu-truong-o-huechuyen-sang-day-hoc-truc-tuyen-i634106/

[CDC Son La] Son La Center for Disease control. 2021. Update on the situation of Covid-19 epidemic in Son La.CDC Son La. Accessed 15 November 2021. http:// cdcsonla.gov.vn/ttksb/80/1594/3233/24399/Phong-chong-benh-truyen-nhiem/Cap-nhat-dich-benh-Covid-19tren-dia-ban-tinh-Son-La-.aspx

Department of Social Protection, Ministry of Labor, Invalids and Social Affairs and Department of Labor, Invalids and Social Affairs. 2020. Rapid assessment of social support needs of children and families affected by the covid-19 pandemic in Vietnam.

Dinh T. 2021. Son La agricultural products overcome the COVID-19 pandemic. Son La newspaper. Accessed 15 November 2021. http://www.baosonla.org.vn/vi/bai-viet/ nong-san-son-la-vuot-qua-dai-dich-covid19-36435

Duong NP, Pham T, Le TT, Nguyen TDH and Do TTA. 2021. Impact of payment for forest environmental services in Thua Thien Hue on the socio-economic life of the community: Lessons from A Luoi district, Thua Thien Hue province. Working Paper 225. Bogor, Indonesia: CIFOR

Duy B. 2021. Supporting ethnic minorities to overcome difficulties caused by the COVID-19 epidemic. Online newspaper Communist Party of Vietnam. Accessed 15 November 2021. https://dangcongsan.vn/phong-chongdich-covid-19/ho-tro-nguoi-dan-toc-thieu-so-vuot-quakho-khan-do-dich-covid-19-589419.html

[GSO] General Statistics Office. 2020. Report on socioeconomic situation in the fourth quarter and 2020. GSO. Accessed 15 November 2021. https://www.gso.gov.vn/ du-lieu-va-so-lieu-thong-ke/2020/12/baocao-tinh-hinhkinh-te-xa-hoi-quy-iv-va-nam-2020/
[GSO] General Statistics Office. 2021. Report on socioeconomic situation in the third quarter and 9 months of 2021. General Statistics Office. Accessed 15 November 2021. https://www.gso.gov.vn/du-lieu-va-so-lieu-thongke/2021/09/bao-cao-tinh-hinh-kinh-te-xa-hoi-quy-iii-va-9thang-nam-2021/

Hau T. 2021. Thua Thien Hue has 247 newly established businesses in the first quarter. Vietnam Economic News. Accessed 16 November 2021. https://congthuong.vn/ thua-thien-hue-co-247-doanh-nghiep-thanh-lap-moi-trongquy-i-155033.html

Hoang L. 2021. Credit empowers businesses. Thua Thien Hue Online Newspaper. Accessed 16 November 2021. https:// baothuathienhue.vn/tin-dung-tiep-suc-cho-doanhnghiep-a85744.html

Huu Q. 2021. Support workers in Son La affected by the COVID-19 epidemic. Vietnam News Agency. Accessed 15 November 2021. https://ncov.vnanet.vn/tin-tuc/ho-tronguoi-lao-dong-o-son-la-bi-anh-huong-dich-covid19/56d9e86b-015b-40b3-aed1-49a49744aec8

Huyen T. 2021. Muong La, Song Ma, Phu Yen recorded 9 more F0 cases returning from epidemic areas. Son La Online Newspaper. Accessed 15 November 2021. http://www. baosonla.org.vn/vi/bai-viet/muong-la-song-ma-phu-yenghi-nhan-them-9-ca-f0-tro-ve-tu-vung-dich-45054

Khanh Q. 2021. Thua Thien Hue: Supporting 1,600 businesses facing difficulties due to the Covid-19 epidemic. MOLISA. Accessed 15 November 2021. http://laodongxahoi.net/thuathien-hue-ho-tro-1600-doanh-nghiep-gap-kho-khan-dodich-covid-19-1319868.html

Le H. 2021. Son La: Many solutions to consume agricultural products in the context of the Covid-19 epidemic. Audit Newspaper. Accessed 15 November 2021. http:// baokiemtoannhanuoc.vn/kinh-te---xa-hoi/son-la-nhieugiai-phap-tieu-thu-nong-san-trong-boi-canh-dichcovid-19-149453

Le NT. 2021. Report on survey results assessing the impact of the Covid-19 epidemic on production and business activities of enterprises in Thua Thien Hue province. Thua Thien Hue Provincial Statistics Office. Accessed 15 November 2021. http://thongkethuathienhue.gov.vn/tin-tuc-su-kien/ tin-hoat-dong-nganh/171/bao-cao-ket-qua-khao-sat-danhgia-tac-dong-cua-dich-covid19-den-hoat-dong-san-xuatkinh-doanh-cua-doanh-nghiep-tren-dia-ban-tinh-thuathien-hue

Luong NG. 2020. Impact of the Covid-19 pandemic on the economic development of Son La province. Son La Provincial Department of Justice. Accessed 15 November 2021. https://sotuphap.sonla.gov. vn/1303/31661/61890/561847/van-ban-phap-luat-vepbgdpl/anh-huong-cua-dai-dich-covid-19-den-phat-trienkinh-te-cua-tinh-son-la.html

Mai T. 2021. Online conference to assess the prevention and control of COVID-19 epidemic in Son La province and implement epidemic prevention and control in the near 
future. CDC Son La. Accessed 15 November 2021. http:// cdcsonla.gov.vn/ttksb/80/1594/3580/28919/Y-TE-SON-LA/ Hoi-nghi-truc-tuyen-Danh-gia-cong-tac-phong--chongdich-COVID-19-tren-dia-ban-tinh-Son-La-va-trien-khai-congtac-phong--chong-dich--trong-thoi-gian-toi.aspx

Minh T. 2021. Son La city attracts urban development projects. Son La Newspaper. Accessed 15 November 2021. http:// baosonla.org.vn/vi/bai-viet/thanh-pho-son-la-thu-hut-cacdu-an-phat-trien-do-thi-41065

[MOLISA] Ministry of Labour - Invalids and Social Affairs. 2021a. Decision No. 1220/QD-LDTBXH on the publication of administrative procedures within the scope of state management functions of the Ministry of Labor, War Invalids and Social Affairs on the implementation of policies to support employees and employers affected by the COVID-19 pandemic from the Unemployment Insurance Fund. Hanoi, Vietnam.

[MOLISA] Ministry of Labour - Invalids and Social Affairs. 2021b. Decision No. 1013/QD-LDTBXH on support for children of pregnant women infected with COVID-19. Hanoi, Vietnam.

National Assembly Standing Committee. 2021. Resolution No. 406/NQ-UBTVQH15 on the issuance of a number of solutions to support businesses and people affected by the COVID-19 epidemic. Hanoi, Vietnam.

Nguyen C and Duy D. 2021. Son La actively stimulates tourism demand when the COVID-19 epidemic is under control. Vietnam News Agency. Accessed 15 November 2021. https:// ncov.vnanet.vn/tin-tuc/son-la-chu-dong-kich-cau-du-lichkhi-dich-covid-19-duoc-kiem-soat/4622b961-6061-4d0689d8-4dcfda7612d0

Nguyen C and Duy D. 2021a. Son La supports workers and businesses affected by the COVID-19 epidemic. Newspaper - VNA. Accessed 15 November 2021. https://baotintuc. vn/chinh-sach-va-cuoc-song/son-la-ho-tro-nguoi-laodong-va-co-so-kinh-doanh-bi-anh-huong-do-dichcovid19-20210828105009982.htm

Nguyen C. 2021. Son La supports businesses, cooperatives and business households in the context of the COVID19 epidemic. Photo Newspaper of Ethnic Minorities and Mountains - VNA. Accessed 15 November 2021. https:// dantocmiennui.vn/son-la-ho-tro-doanh-nghiep-hop-tac-xaho-kinh-doanh-trong-boi-canh-dich-covid19/306914.html

Nguyen TH. 2021. Son La: Accompanying farmers during the epidemic season. Online newspaper Communist Party of Vietnam. Accessed 15 November 2021. https:// dangcongsan.vn/kinh-te/son-la-dong-hanh-cung-nongdan-trong-mua-dich-591436.html

Nguyet A. 2021. Thua Thien Hue rushes to pay support to workers affected by the COVID-19 epidemic. Website of the Department of Labour, Invalids and Social Affairs. Accessed 15 November 2021. https://sldtbxh.thuathienhue.gov. $\mathrm{vn} / \mathrm{gd}=39 \& \mathrm{cn}=28 \& \mathrm{tc}=13528$

Nhat A. 2021. Thua Thien Hue: Protecting anti-epidemic achievements, promoting economic development. Online Newspaper of the Government. Accessed 15 November 2021. http://baochinhphu.vn/Hoat-dong-dia-phuong/Thua-Thien-
Hue-Bao-ve-thanh-qua-chong-dich-thuc-day-phat-trienkinh-te/449387.vgp

Online Newspaper of the Government. 2021. Policy to support difficulties due to the COVID-19 epidemic in Thua Thien Hue. Online Newspaper of the Government.. Accessed 15 November 2021. http://baochinhphu.vn/Tra-loi-congdan/Chinh-sach-ho-tro-kho-khan-do-dich-COVID19-taiThua-Thien-Hue/450764.vgp

P V. 2021. Son La supports workers who go to work in the southern provinces to return to stabilize their lives. Website of the Central Committee of the Vietnam Fatherland Front Agency of the Central Committee of the Vietnam Fatherland Front. Accessed 15 November 2021. http://mattran.org.vn/ tin-tuc/son-la-ho-tro-cong-nhan-di-lao-dong-tai-cac-tinhphia-nam-tro-ve-on-dinh-cuoc-song-40564.html

People's Committee of Thua Thien Hue province. 2021a. Regulations on extending the deadline for payment of value added tax, corporate income tax, personal income tax and land rent in 2021. Portal of Thua Thien Hue province. Accessed 15 November 2021. https://thuathienhue.gov. vn/vi-vn/Chinh-sach-moi/tid/Quy-dinh-gia-han-thoi-hannop-thue-gia-tri-gia-tang-thue-thu-nhap-doanh-nghiepthue-thu-nhap-ca-nhan-va-tien-thue-dat-trong-nam-2021/ newsid/5498FF56-D7A0-4960-A3EC-AD12010D1A85/cid/ EB22014C-96F5-498F-9DB4-C03213F09B79

People's Committee of Thua Thien Hue province. $2021 \mathrm{~b}$. Implement policies to support people facing difficulties due to the Covid-19 pandemic. Portal of Thua Thien Hue province. Accessed 15 November 2021. https:// thuathienhue.gov.vn/vi-vn/Tin-tuc-su-kien/tid/Trienkhai-chinh-sach-ho-tro-nguoi-dan-gap-kho-khando-dai-dich-Covid-19/newsid/B2FE1B56-064C-459EAECA-ADA500FFC6D7/cid/2BEA0540-FCA4-4F81-99F26E8848DC5F2F

Pham TT, Tran NMH and Hoang TL. 2021. Impacts of Covid-19 and Payment for Forest Environmental Services on Rural Women in Moc Chau district, Son La province. Infobrief 350. Bogor, Indonesia: CIFOR.

Portal of Son La province 2021c. The Committee for Ethnic Minority Affairs provides financial support for ethnic minorities and students in difficult circumstances infected with Covid-19. Son La Department of Natural Resources and Environment. Accessed 15 November 2021. https://sonla. gov.vn/4/469/61790/619398/thong-tin-che-do-chinh-sachmoi/-uy-ban-dan-toc-ho-tro-kinh-phi-cho-dong-bao-vahoc-sinh-nguoi-dan-toc-thieu-so-co-hoan-canh-kho

Portal of Son La province. 2021a. List of projects attracting investment in Son La province in the period of 2021 - 2025. Son La Department of Natural Resources and Environment. Accessed 15 November 2021. https://sotnmt.sonla.gov. vn/1292/31148/63504/605671/du-an-dau-tu/danhmuc-du-an-thu-hut-dau-tu-tren-dia-ban-tinh-son-la-giaidoan-2021-2025

Portal of Son La province. 2021b. By the end of October 20, 2021, Son La province disbursed public investment 
capital, reaching $48.1 \%$ of the assigned capital plan. Son La Department of Natural Resources and Environment. Accessed 15 November 2021. https://mocchau.sonla.gov. vn/4/469/61723/623923/tin-kinh-te/den-het-ngay-20-102021-tinh-son-la-giai-ngan-von-dau-tu-cong-dat-48-1-kehoach-von-giao

Portal of the Ethnic Committee. 2020. Financial support for ethnic minority women affected by the Covid-19 pandemic. Portal of the Ethnic Committee. Accessed 15 November 2021. http://www.cema.gov.vn/phong-chongdich-covid-19/thong-tin-tuyen-truyen/ho-tro-tien-chophu-nu-dan-toc-thieu-so-bi-anh-huong-boi-dai-dichcovid-19.htm

Prime Minister. 2021. Decision No. 27/2021/QD-TTg on the reduction of land rent in 2021 for those affected by the Covid19 epidemic. Hanoi, Vietnam.

Son La Provincial People's Committee. 2021. Decision No. 2270/QD-UBND on regulations on support policies for employees without labor contracts who lose their jobs due to the Covid-19 pandemic in Son La province. Son La, Vietnam.

Son La Provincial People's Council. 2021. Resolution No. 04/2021/NQ-HDND stipulating a number of support policies in the prevention and control of the Covid-19 epidemic in Son La province. Son La, Vietnam.

Thai H. 2021. Hue City: urgently pay timely support to workers affected by the Covid-19 epidemic. Hue city portal. Accessed 15 November 2021. https://huecity.gov. vn/Bao-chi-va-truyen-thong-Hue/tid/Thanh-pho-Hue-
Khan-truong-chi-tra-ho-tro-kip-thoi-cho-nguoi-lao-donganh-huong-boi-dich-COVID-19.html/pid/26281/cid/236

Thu H. 2021. Son La detected 33 positive cases from the southern provinces and cities. Thanh nien Online. Accessed 15 November 2021. https://thanhnien.vn/son-la-phathien-33-ca-duong-tinh-ve-tu-cac-tinh-thanh-phia-nampost1393552.html

Thu T. 2021a. How does Son La solve the job problem for tens of thousands of workers returning from others provinces? VOV Electronic Newspaper. Accessed 15 November 2021. https://vov.vn/xa-hoi/son-la-giai-bai-toanviec-lam-cho-hang-chuc-ngan-lao-dong-tu-tinh-ngoai-trove-ra-sao-899724.vov

Thu T. 2021b. Son La added 3 more COVID-19 cases, all workers returning from Binh Duong. VOV Electronic Newspaper. Accessed 15 November 2021. https://vov.vn/ xa-hoi/tin-24h/son-la-them-3-ca-mac-covid-19-deu-la-laodong-ve-tu-binh-duong-896573.vov

Thuy D. 2021. Son La Provincial Social Security: Actively and proactively implementing Resolution 116/NQ-CP of the Government. Online newspaper Communist Party of Vietnam. Accessed 15 November 2021. https://dangcongsan.vn/ bao-hiem-xa-hoi-bao-hiem-y-te-vi-an-sinh-xa-hoi/tin-tuc/ bhxh-tinh-son-la-tich-cuc-chu-dong-trien-khai-nghi-quyet116-nq-cp-cua-chinh-phu-593916.html

[VSS] Vietnam Social Security. 2021. Official Dispatch No. 2311/BHYT-CYST on the advance, payment and settlement of medical examination and treatment expenses covered by health insurance. Hanoi, Vietnam.
GENDER Platform CGIAR
This work has been carried out under the CGIAR GENDER Platform, which is grateful for the support of CGIAR Trust Fund Contributors. www.cgiar.org/funders
This research was carried out by CIFOR as part of the CGIAR Research Program on Forests, Trees and Agroforestry (FTA). FTA is the world's largest research for development program to enhance the role of forests, trees and agroforestry in sustainable development and food security and to address climate change. CIFOR leads FTA in partnership with Bioversity International, CATIE, CIRAD, INBAR, ICRAF and TBI.

FTA's work is supported by the CGIAR Trust Fund: cgiar.org/funders/ 